\title{
Evaluation of Solar Energy Potential for the Red Sea Project, Kingdom of Saudi Arabia
}

\author{
Ahmad Siouti, Atef Belhaj Ali \\ Department of Geography and GIS, Faculty of Arts and Humanities, King Abdul Aziz University, Jeddah, KSA \\ Email: amalhabeb@kau.edu.sa
}

How to cite this paper: Siouti, A. and Belhaj Ali, A. (2019) Evaluation of Solar Energy Potential for the Red Sea Project, Kingdom of Saudi Arabia. Natural Resources, 10, 96-114.

https://doi.org/10.4236/nr.2019.104007

Received: March 17, 2019

Accepted: April 19, 2019

Published: April 22, 2019

Copyright ( 2019 by author(s) and Scientific Research Publishing Inc. This work is licensed under the Creative Commons Attribution International License (CC BY 4.0).

http://creativecommons.org/licenses/by/4.0/

(c) (i) Open Access

\begin{abstract}
There has been extreme utilization of petroleum derivatives in recent decades for the generation of electrical vitality, which is contaminating nature in a regularly expanding approach to respond to the exponential demand for electrical power. In light of the essential vision of Saudi Arabia's government towards the fractional change of reliance on oil as a national wellspring of economy, there is consideration for dependence on resources available inside the country, especially the potentials of renewable sources as alternatives. Saudi Arabia appreciates its geographical advantage inside the sun-belt zone, which has the most impressive sun-situated radiation total on earth. It is a correlative ideal position to consider interest in this valuable asset, through which it can achieve its vision by virtue of its promising whole deal prospects. This study highlights an approach for creating sunlight-based maps that examines the intensity of sun-radiation and its viability to deliver power. The system is to record the measures of sunlight radiation from several allocated data acquisition sites over the study area and balance them with the standard count, and later, make a sun-map in light of the yield. Likewise, the study will register the rate of energy from sun-situated radiation for the area and make preliminary proposals for the achievement of this test.
\end{abstract}

\section{Keywords}

Solar Energy, GHI, DNI, DHI, Photovoltaics, Red Sea Project

\section{Introduction}

The geographic location of the Red Sea Project has the enormous advantage of plentiful solar radiation throughout the year. Solar energy can provide a great opportunity for reduced energy costs and easier locally distributed access to energy [1] [2] [3] [4]. The spatial mapping of the potential resources of renewa- 
ble energy gives the opportunity for integrated regional planning and provides a tool for efficient and accurate decision-making concerning the available natural resources of the area. The aim of this paper is to evaluate the solar energy potential of the Red Sea Project Area. For this purpose, it is important to acquire the datasets and information for the specific area of interest in the spatial detail that is needed for this research and further visualize its potential in order to support the decision makers to steer toward the solar energy approach.

It was once a technological breakthrough to supply each home with energy using a centralized energy distribution model (Figure 1). This model was successful in providing the sum of the population with a very important survival aspect. This model as it began successfully carried on for decades until it became dysfunctional in two major ways: Firstly, the environmental side effects. Carbon, the main fuel for electricity is very toxic for the environment, especially around areas where large electric generation plants were built, that provide electricity to the cities. Secondly, in places located the farthest from the city, whenever an outage takes place, those areas would remain without electricity for long periods of time as they were the last to have the electricity supply restored [5]. These areas could have energy independence if they took advantage of their local power possibilities.

As these facts became prevalent there was a new trend and the international com-munities' councils started looking for alternative solutions that could mediate these problems. It is a common occurrence nowadays that rural communities are adopting a new model of energy supply, one that is locally generated. Uncovering local energy potential is not a simple task though. To identify the local renewable energy potential in each place is a multi-disciplinary task and that is where the use of Geographic Information Systems (GIS) comes in play [6] [7].

Saudi Arabia's economy is oil dependent. As a result, the ever-increasing consumption of oil as shown in Figure 2 is putting oil exports at risk and is holding back the growth rate of the economy [8]. On the other hand, energy production from crude oil raises the cost of kilowatt-hours. In this sense, the leadership must seriously consider alternative and sustainable sources wherever this asset can be available.

\section{Solar Energy}

Renewable energy sources are directly (photovoltaic systems) and indirectly (wind, water, etc.) interrelated with the sun. Inevitably, almost all organisms rely, either directly or indirectly, on solar energy for their survival and maintenance [9] [10].

The sunlight reaching the Earth's surface is ten thousand times more than the average power consumed by humans in 2005 [10]. Solar Energy represents one of the newly adopted approaches for reducing greenhouse gas emissions. Of all the renewable energies, solar energy has the advantage of being easier to predict 
Distribution lines carry electricity to houses

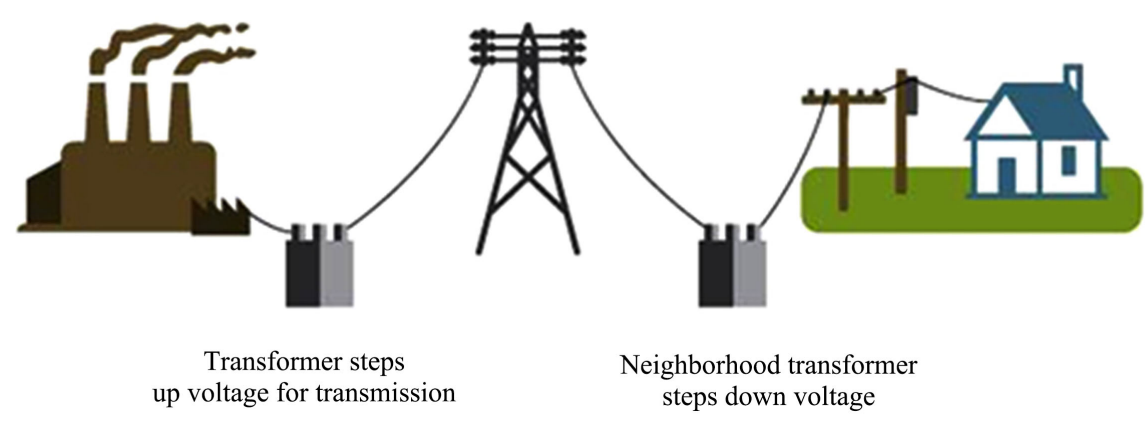

Figure 1. Power Distribution Model (Electricity generation, transmission and distribution). Source: Image from National Energy Education Development Project (https://briterbridges.com).

Saudi Arabia SAU Electric power consumption (kWh per capital)

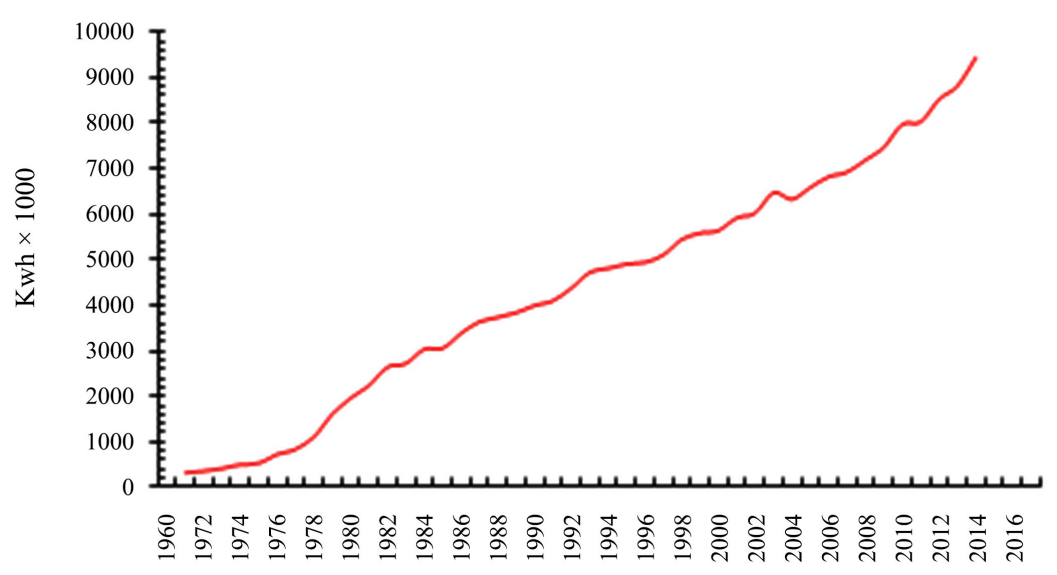

Figure 2. Power Consumption Saudi Arabia. Source:

https://data.worldbank.org/indicator/EG.USE.ELEC.KH.PC?end=2014\&locations=SA\&st $\underline{\operatorname{art}=1986 .}$

and is more consistent throughout the year than the other energy forms [11]. Solar irradiation is the irradiance in $\mathrm{W} / \mathrm{m}^{2}$ over a time period and it is measured in $\mathrm{Wh} / \mathrm{m}^{2}$. It is measured with specialized sensors that are used in the field.

\subsection{Direct Normal Irradiance (DNI)}

One important key element of solar irradiation is Direct Normal Irradiance (DNI). This indicator of solar irradiation is the direct irradiance received on an area perpendicular to the sun over the total solar spectrum. DNI is calculated over cloudless conditions and it is measured on site by receptors. It is used to calculate the solar power potential of an area. The precise definition that is used to avoid confusion is this: "Direct irradiance is the quotient of the radiant flux on a given plane receiver surface received from a small solid angle centered on the sun's disk to the area of that surface. If the plane is perpendicular to the axis 
of the solid angle, direct normal solar irradiance is received." ISO 9488:1999 (https://www.iso.org/).

It is measured in kilowatt-hours per square meter per day and usually provided as an average per year.

\subsection{Diffuse Horizontal Irradiance (DHI)}

Diffused Horizontal Irradiance (DHI) is the amount of diffused solar radiation that reaches a surface indirectly in the form of scattered molecules and particles measured per unit area. It is basically energy that does not come from the beam of the sun. It also is measured on site by blocking the projected area of the sun from the receptors surface. It can be measured either directly by the appropriate instruments (pyrometers) or indirectly by the relationship between GHI and DHI (see Equation (1)). This is radiation is represented by the horizontal line as shown in the Figure 3.

\subsection{Global Horizontal Irradiance (GHI)}

Global Horizontal Irradiance (GHI) is the total amount of radiation that is received by a surface that is horizontal to the ground. It is the solar energy that enters the earth's atmosphere before it is diffused by articles in the atmosphere. It is the sum of DNI, ground reflected radiation and the diffused radiation or else named Diffuse Horizontal Irradiance [12]. It is measured through specialized instruments or calculated by the equation:

$$
\mathrm{GHI}=\mathrm{DHI}+\mathrm{DNI} * \cos \theta z, \text { with } \theta z \text { : solar zenith angle (1) }
$$

\subsection{Solar Maps}

A solar map is a map containing information on the amount of sunlight received by a solar cell, a field, a piece of land, or other larger area (Figure 4).

Solar radiation is determined by the topography of the area. It may have additional economic data to help make decisions on future development of an area, but the essential elements of a solar map are Topographic, and Climatic data. That means Slope, Aspect, Shadow, and Orientation (relative to the movement of the sun) are all factors of determining the exposure to the sun in each part of a larger area [13] [14]. For the data to be communicated effectively it has to be served in a front end and back end platform [15]. There are two models of deciphering insolation: the point model and the area model [16]. The point model is considered more accurate for specific small areas, while the area model is used for having the possibility to calculate insolation for an area of choice on demand, from the model generated for the large area.

\section{Study Area}

The area of interest for this research is The Red Sea which is located along the Westen coast of the Kingdom of Saudi Arabia, between the cities of Umluj and Al-Wajh (Figure 5). 


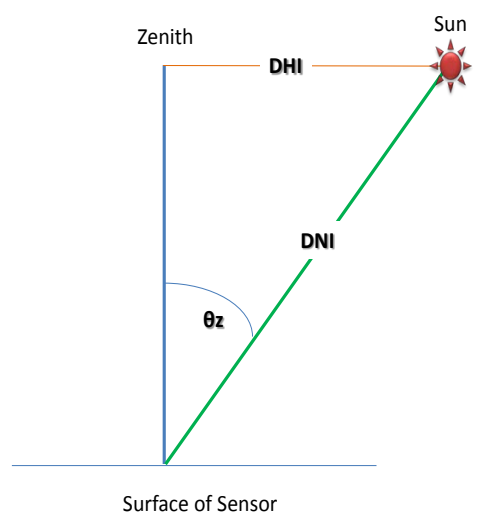

Figure 3. Relationship between GHI and DHI.

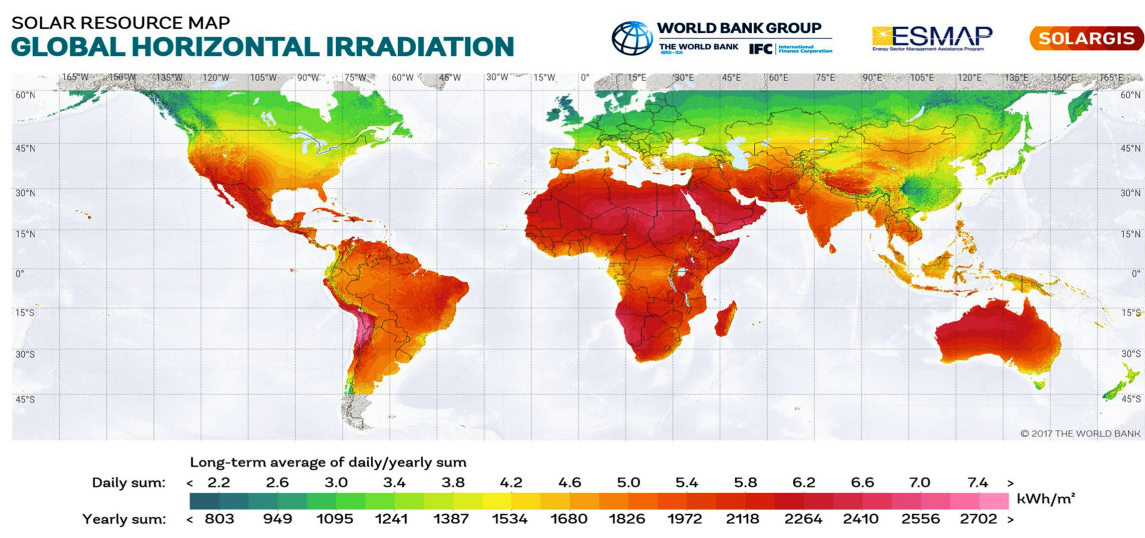

Figure 4. Example of a Global Solar Map. This map represents the average insolation (global horizontal irradiation) where blue colours are the places with the least exposure to sun, and with the pink areas most exposed to sun (Source: SolarGIS, 2013).



Figure 5. Study area, red sea project. 


\subsection{Climate}

The area is characterized by its year-round temperate climate, with average summer temperatures reaching up to $31^{\circ} \mathrm{C}\left(88^{\circ} \mathrm{F}\right)$. According to the Red Sea Project Fact Sheet, this region is envisioned as an exquisite luxury resort destination established across 50 untouched natural islands in a lagoon that stretches along $200 \mathrm{~km}$ (125 miles) of stunning coastline [8].

The area of interest for this research has approximately 85,000 people living on the coasts of the Red Sea. It belongs to the Tabouk Governorate, Saudi Arabia, which has a total population of 455,450 inhabitants (World Population Review).

Environmentally, it is surrounded by desert. Two monsoons define the climate of the Red Sea area. Those monsoons are the result of temperature differences between water surface and land. There are very few rainfalls during the year, averaging $100 \mathrm{~mm}$ (4 in) per year appearing locally as short showers [15]. The average air temperature reaches $39^{\circ} \mathrm{C}\left(102^{\circ} \mathrm{F}\right)$ (Figure 6). The average surface water temperature is about $28^{\circ} \mathrm{C}\left(82^{\circ} \mathrm{F}\right)$ and the average water temperature is $22^{\circ} \mathrm{C}\left(72^{\circ} \mathrm{F}\right)$.

\subsection{Topography}

The Red Sea project is located on the coast between Umluj city and Al-Wajh city. The altitude of the area is in the range of less than 300 feet as shown in Figure 11. The area is surrounded by the al-Hijaz Mountains. Following maps show the $3 \mathrm{D}$ view, altitude, aspect, hillshade, and slope of the study area (Figure 7, Figure 8, Figure 9, Figure 10, Figure 11).

\section{Methodology}

To perform the quantitative analysis, certain data are required to be allocated from the data sources such as:

- Direct Normal Irradiance DNI;

- Global Horizontal Irradiance GHI;

- Diffused Irradiance DHI.

These data were collected by ground measurement stations operated by King Abdullah City for Atomic and Renewable Energy (KACARE). DHI and GHI data are measured by Pyranometer with a measurement resolution of 1 minute and a nominal uncertainty of $\pm 2 \%$. DNI was measured by pyrheliometer with a measurement resolution of 1 minute and a nominal uncertainty of $\pm 2 \%$ (Figure 12).

For this study, daily and monthly averages were calculated from the values gathered by ground stations, covering a period from August 2013 to May 2017. For the data analysis shown in the next sections, all gathered data for each variable (DNI, GHI, DHI) were controlled and analyzed to determine trend and pattern for the study area. 


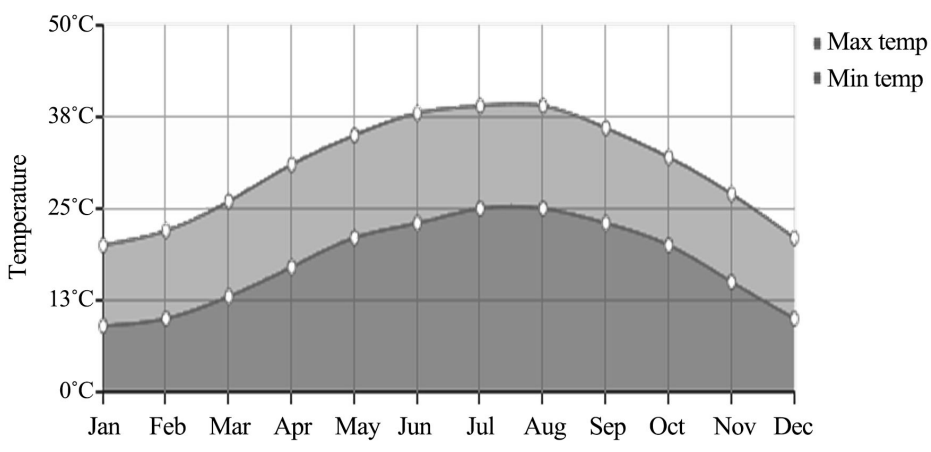

Figure 6. Annual Temperature Averages, Tabuk Governorate (Source: https://www.timeanddate.com/weather).



Figure 7. 3D Model Overview.

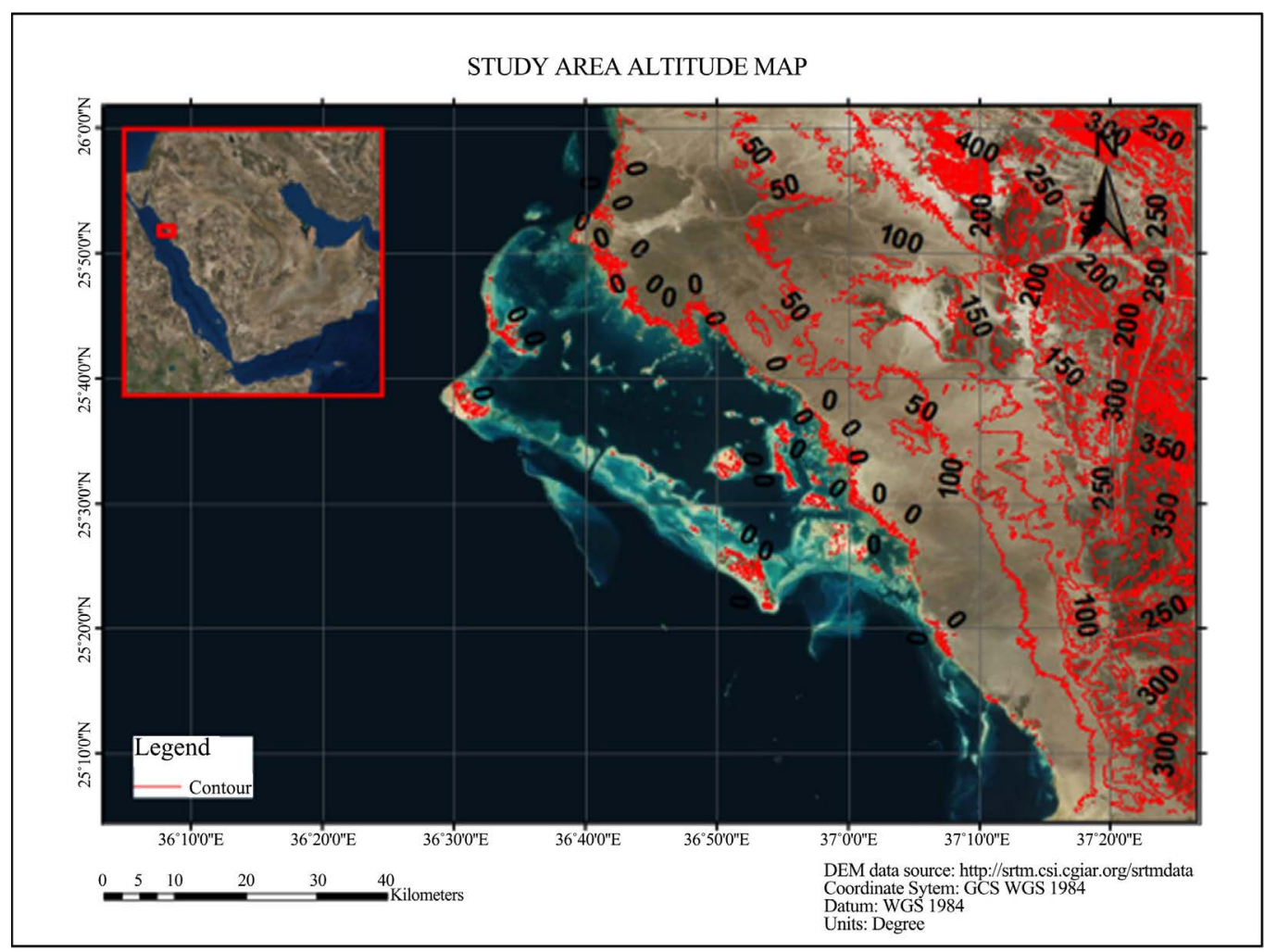

Figure 8. Red Sea project Area Topographic Map. 




Figure 9. HillShade map.

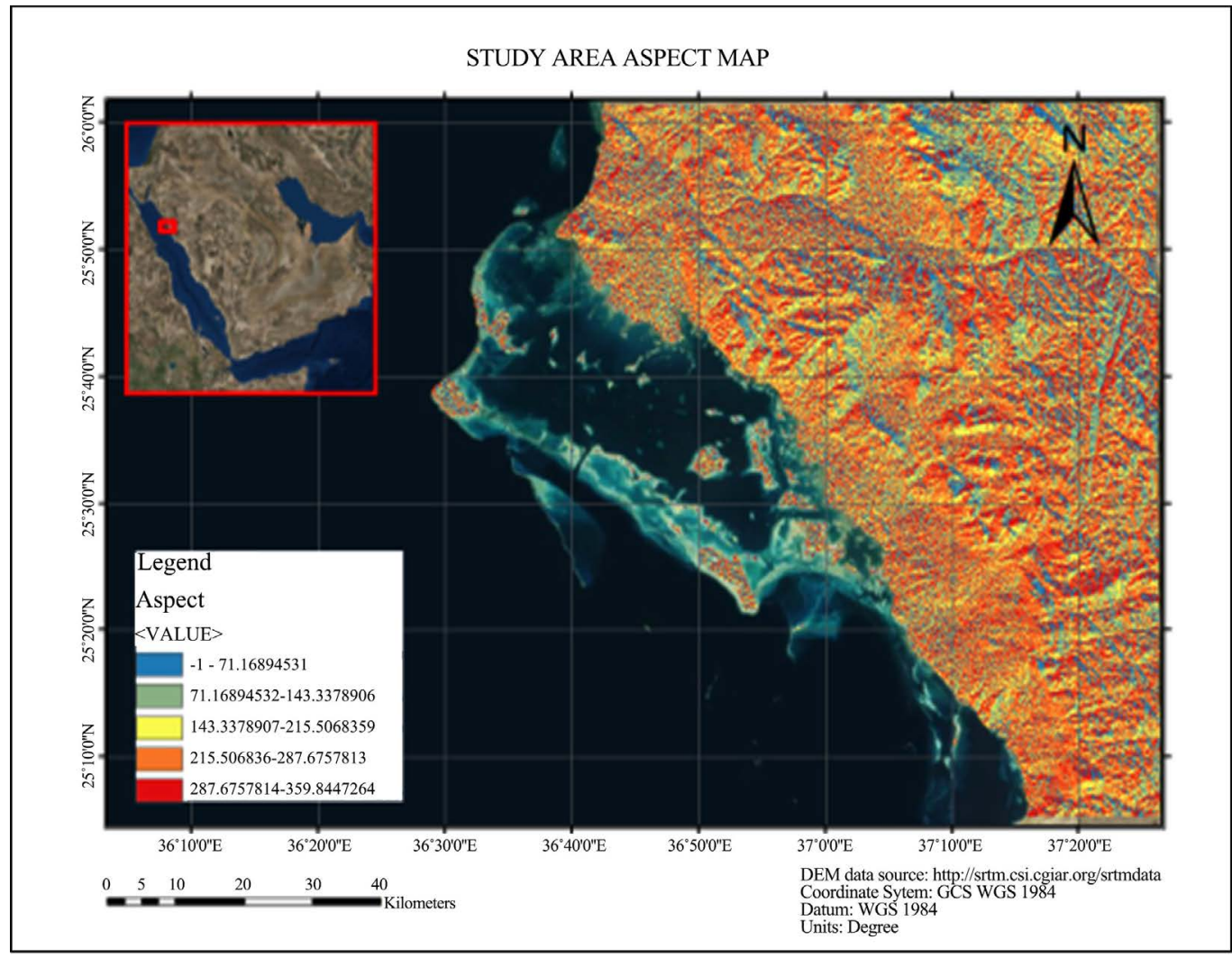

Figure 10. Study area aspect map. 


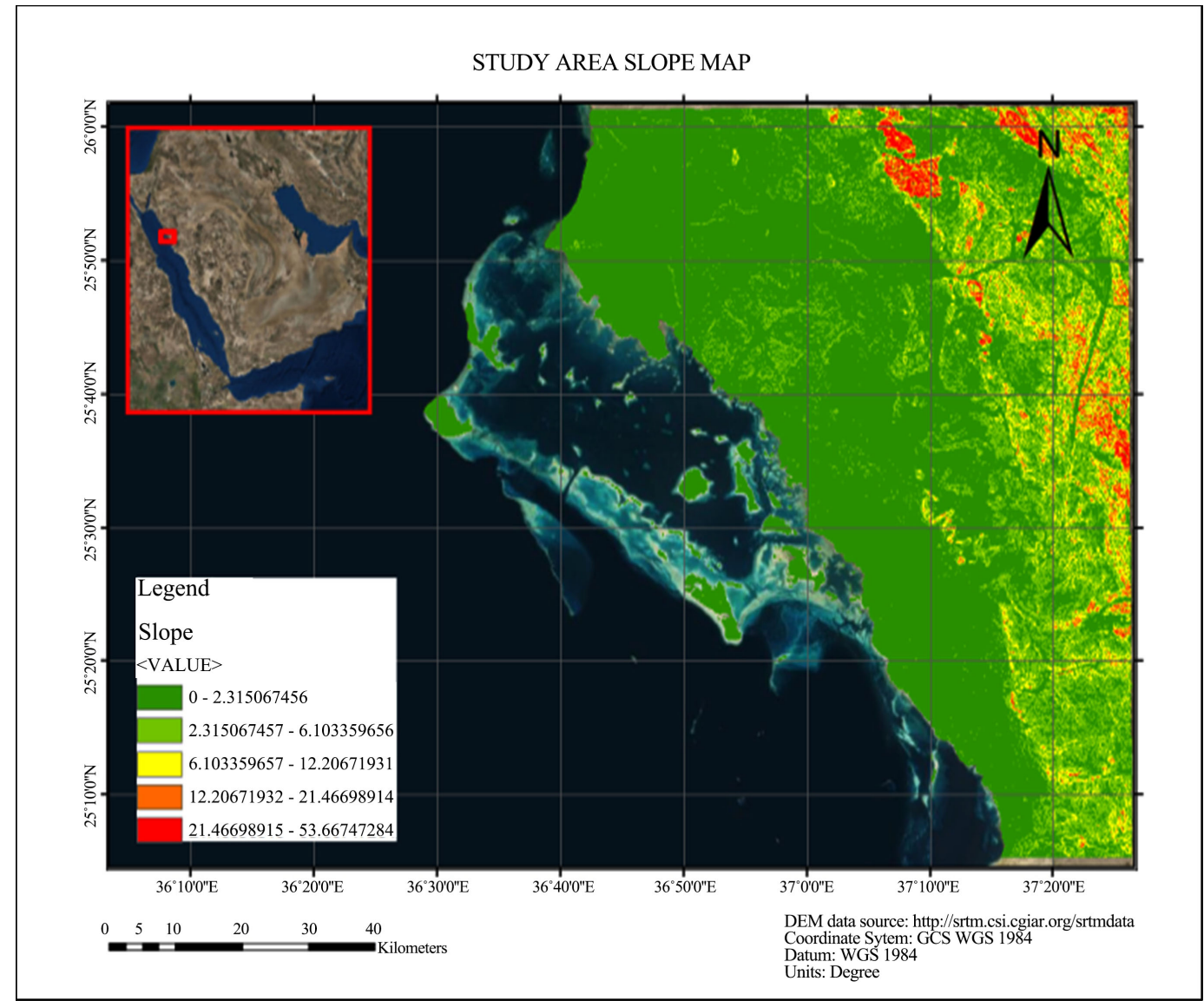

Figure 11. Study area slope map.

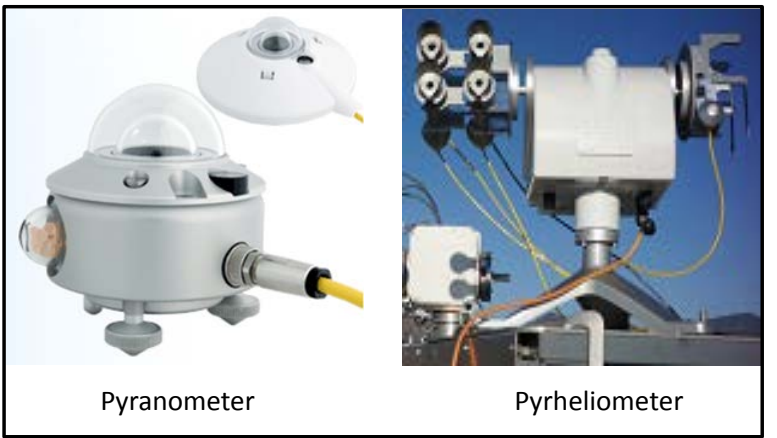

Figure 12. Equipements used for data collection (source: KACARE).

\subsection{Data Gathering}

The data used in this study is based on almost four years (Table 1) of solar resource measurements (GHI, DHI and DNI), three main data sources will be used to acquire solar data for the study area from KACARE (King Abdullah City for Atomic and Renewable Energy) metrology network (Figure 13).

- Umluj solar station (site 1),

- Al-Wajh solar station (site 2),

- Duba solar station (site 3).

We also used data derived from satellite provided by NASA via their Power 
data access viewer portal (https://power.larc.nasa.gov/data-access-viewer/). GHI data are extracted and downloaded from this portal covers from January 2000 to March 2018 with a resolution of 1 degree $\times 1$ degree.

Table 1 shows the data of average monthly Global Horizontal Irradiance, average monthly Direct Normal Irradiance and average monthly Global Horizontal Irradiance collected for the period 2013-2017 gathered by the three stations (Umluj, Al-Wajh and Duba).

As shown in Figure 14, GHI average corresponds to the below trend equation

$$
y=4.1308 x+5896.8
$$

this equation shows that is a very slight increment along the time period of the data.

Table 1. Average of GHI, DNI and DHI gathered by the three stations (Umluj, Al-Wajh and Duba).

\begin{tabular}{|c|c|c|c|c|c|c|c|c|c|c|c|c|c|c|c|}
\hline \multirow{3}{*}{ Month } & \multirow{3}{*}{ station } & \multicolumn{2}{|r|}{2013} & \multicolumn{3}{|c|}{2014} & \multicolumn{3}{|c|}{2015} & \multicolumn{3}{|c|}{2016} & \multicolumn{3}{|c|}{2017} \\
\hline & & GHI & DNI DHI & GHI & DNI & DHI & GHI & DNI & DHI & GHI & DNI & DHI & GHI & DNI & DHI \\
\hline & & & & average & average & average & average & average & average & average & average & average & average & average & average \\
\hline \multirow{4}{*}{ JAN } & $\begin{array}{l}\text { Umluj } \\
\text { station }\end{array}$ & & & 4433.0 & 6137 & 1215.3 & 4414.5 & 6051 & 1258.7 & 4483.7 & 5658.4 & 1491.7 & 4448.2 & 6085.1 & 1233.7 \\
\hline & $\begin{array}{c}\text { Al-Wajh } \\
\text { station }\end{array}$ & & & 4356.1 & 6214.4 & 1194.7 & 4503.9 & 6367.9 & 1231.8 & 4228.4 & 5580.6 & 1395.7 & 4200.7 & 5446 & 1323.6 \\
\hline & $\begin{array}{c}\text { Duba } \\
\text { station }\end{array}$ & & & 4288.5 & 6519.4 & 1040.9 & 4278.5 & 6188.2 & 1210.2 & 4390.5 & 6495.9 & 1175.1 & 4044.4 & 5473 & 1299 \\
\hline & $\begin{array}{l}\text { Umluj } \\
\text { station }\end{array}$ & & & 5496.7 & 6968.9 & 1366.8 & 5037.2 & 5042.1 & 1981.3 & 5583.6 & 6989.6 & 1433.6 & 5284.5 & 5960.5 & 1716.4 \\
\hline \multirow[t]{3}{*}{ FEB } & $\begin{array}{l}\text { Al-Wajh } \\
\text { station }\end{array}$ & & & 5422.9 & 7340.9 & 1236.4 & 4967.4 & 5011.7 & 2000.5 & 5517.5 & 7198.4 & 1367.6 & 5057.4 & 6045.2 & 1525.6 \\
\hline & $\begin{array}{c}\text { Duba } \\
\text { station }\end{array}$ & & & 5385.1 & 7638.9 & 1107.5 & 4833.8 & 5323.6 & 1734.7 & 5492.1 & 7722.4 & 1144.8 & 5226.7 & 6666.4 & 1447.2 \\
\hline & $\begin{array}{l}\text { Umluj } \\
\text { station }\end{array}$ & & & 6127.1 & 5666.9 & 2207.7 & 6099.5 & 5739.8 & 2205 & 5733.2 & 4759.3 & 2496.5 & 6148.7 & 6196.2 & 2006.1 \\
\hline \multirow[t]{3}{*}{ MAR } & $\begin{array}{c}\text { Al-Wajh } \\
\text { station }\end{array}$ & & & 5989.7 & 5882.9 & 2035 & 6134.6 & 6066.6 & 2065 & 5860.7 & 5849 & 2079.7 & 5541.5 & 5803.6 & 1725 \\
\hline & $\begin{array}{c}\text { Duba } \\
\text { station }\end{array}$ & & & 5843.8 & 5880.6 & 1930.4 & 5973.3 & 6072.6 & 1967 & 5774 & 5646 & 2052.3 & 6089.8 & 6797.4 & 1688.2 \\
\hline & $\begin{array}{l}\text { Umluj } \\
\text { station }\end{array}$ & & & 6636.1 & 5531.9 & 2538.7 & 7239.9 & 6300.2 & 2659 & 7214.3 & 7093.6 & 2095.6 & 6404.3 & 4908.7 & 2766.8 \\
\hline \multirow[t]{2}{*}{ APR } & $\begin{array}{c}\text { Al-Wajh } \\
\text { station }\end{array}$ & & & 6744.5 & 5723.3 & 2587.1 & 7495.8 & 7173.9 & 2325 & 7311.2 & 7652.7 & 1882.1 & 6136.7 & 5170.5 & 2389.2 \\
\hline & $\begin{array}{l}\text { Duba } \\
\text { station }\end{array}$ & & & 6903 & 6172.5 & 2452.8 & 7474.3 & 7355.4 & 2193.3 & 7230.4 & 7477.2 & 1941.5 & 6394.9 & 5691.7 & 2330.9 \\
\hline \multirow{2}{*}{ MAY } & $\begin{array}{l}\text { Umluj } \\
\text { station }\end{array}$ & & & 7165.3 & 6076.2 & 2584.7 & 7134.2 & 5919.9 & 2644.5 & 7835.1 & 7681.8 & 2111.6 & 7035.7 & 6147.7 & 2419.5 \\
\hline & $\begin{array}{c}\text { Al-Wajh } \\
\text { station }\end{array}$ & & & 7576.3 & 7350.9 & 2169.6 & 7328.7 & 6409 & 2562.7 & 7982.2 & 7920.5 & 2112.9 & 7123.6 & 6746.4 & 2143.7 \\
\hline
\end{tabular}




\section{Continued}

\begin{tabular}{|c|c|c|c|c|c|c|c|c|c|c|c|c|c|c|c|c|}
\hline & $\begin{array}{c}\text { Duba } \\
\text { station }\end{array}$ & & & & 7544.3 & 7403.2 & 2113.6 & 7616.4 & 6998.4 & 2476.8 & 7834.5 & 7770 & 2103.2 & 7236.6 & 7278.6 & 1884.1 \\
\hline & $\begin{array}{l}\text { Umluj } \\
\text { station }\end{array}$ & & & & 7803.3 & 7430.8 & 2233.1 & 7873.1 & 7445.8 & 2325.9 & 7912.4 & 7555 & 2249.4 & & & \\
\hline \multirow[t]{3}{*}{ JUN } & $\begin{array}{c}\text { Al-Wajh } \\
\text { station }\end{array}$ & & & & 8022.4 & 8169.7 & 2014.4 & 8138.6 & 8151.6 & 2127.2 & 8274.4 & 8561.4 & 1954.3 & & & \\
\hline & $\begin{array}{l}\text { Duba } \\
\text { station }\end{array}$ & & & & 8067.5 & 8402.7 & 1917.2 & 8090.9 & 8290.3 & 2004.7 & 8077.6 & 8204 & 1992.9 & & & \\
\hline & $\begin{array}{l}\text { Umluj } \\
\text { station }\end{array}$ & & & & 7716.6 & 8153 & 1702.8 & 7826.4 & 8311.9 & 1713.2 & 7648.3 & 7836.3 & 1844.6 & & & \\
\hline \multirow[t]{3}{*}{ JUL } & $\begin{array}{l}\text { Al-Wajh } \\
\text { station }\end{array}$ & & & & 7784.1 & 8467 & 1608.5 & 7861 & 8488.8 & 1677.3 & 8038 & 8794.2 & 1628.6 & & & \\
\hline & $\begin{array}{c}\text { Duba } \\
\text { station }\end{array}$ & & & & 7855.8 & 8770.2 & 1503.5 & 7865 & 8621.1 & 1594.6 & 7826.5 & 8847.1 & 1431 & & & \\
\hline & $\begin{array}{l}\text { Umluj } \\
\text { station }\end{array}$ & & & & 7028.5 & 6617.6 & 2110.6 & 6527.9 & 4704.7 & 2928 & 6863.2 & 6057.7 & 2333.3 & & & \\
\hline \multirow[t]{3}{*}{ AUG } & $\begin{array}{c}\text { Al-Wajh } \\
\text { station }\end{array}$ & & & & 7232.2 & 7541 & 1768.8 & 6944.9 & 5693.5 & 2652.6 & 7170.1 & 6767.4 & 2215.3 & & & \\
\hline & $\begin{array}{l}\text { Duba } \\
\text { station }\end{array}$ & 7454.3 & 8478.8 & 1450.2 & 7309.7 & 8106.7 & 1534.7 & 7038.2 & 6288.5 & 2342.8 & 7013.3 & 7056.7 & 1908.9 & & & \\
\hline & $\begin{array}{l}\text { Umluj } \\
\text { station }\end{array}$ & 6578.9 & 6511.8 & 1983.6 & 6479.2 & 6735.4 & 1759.9 & 6259.1 & 5445.5 & 2324.1 & 6385 & 6100.5 & 2052.1 & & & \\
\hline \multirow[t]{3}{*}{ SEP } & $\begin{array}{l}\text { Al-Wajh } \\
\text { station }\end{array}$ & & & & 6676.1 & 7809 & 1401 & 6250.9 & 5994.1 & 2061.5 & 6713.8 & 7145.7 & 1773.5 & & & \\
\hline & $\begin{array}{l}\text { Duba } \\
\text { station }\end{array}$ & 6605.2 & 7584.2 & 1500.8 & 6679.7 & 8212.4 & 1224 & 6401.4 & 6632.6 & 1846.7 & 6561 & 7672.3 & 1409.1 & & & \\
\hline & $\begin{array}{l}\text { Umluj } \\
\text { station }\end{array}$ & 5616.3 & 6700.5 & 1424.4 & 5393.6 & 6009.3 & 1634.4 & 5344.1 & 5504.2 & 1848.6 & 5307.7 & 5517.6 & 1782.8 & & & \\
\hline \multirow[t]{3}{*}{ OCT } & $\begin{array}{l}\text { Al-Wajh } \\
\text { station }\end{array}$ & 5774.6 & 7579.9 & 1190.4 & 5315.7 & 6479.7 & 1391.8 & 5256.8 & 5733.7 & 1687.6 & 5597.1 & 6409.4 & 1595.3 & & & \\
\hline & $\begin{array}{l}\text { Duba } \\
\text { station }\end{array}$ & 5662.9 & 7772.4 & 1076.9 & 5312.9 & 6826.2 & 1291.5 & 5331.1 & 6219 & 1533.6 & 5395.1 & 6750.2 & 1308.6 & & & \\
\hline & $\begin{array}{l}\text { Umluj } \\
\text { station }\end{array}$ & 4626.0 & 6439.8 & 1145 & 4683.2 & 6547 & 1120.2 & 4675.2 & 6287.6 & 1229.1 & 4710.3 & 6244 & 1263.8 & & & \\
\hline \multirow[t]{3}{*}{ Nov } & $\begin{array}{l}\text { Al-Wajh } \\
\text { station }\end{array}$ & 4514.3 & 6251.1 & 1185.1 & 4723.6 & 6806.6 & 1137.8 & 4639.9 & 6410.5 & 1221.7 & 4681.9 & 6173.8 & 1342.2 & & & \\
\hline & $\begin{array}{l}\text { Duba } \\
\text { station }\end{array}$ & 4447.3 & 6161.1 & 1192.5 & 4613.4 & 6965.2 & 998.1 & 4426.8 & 6224.8 & 1150.7 & 4353.7 & 5602.1 & 1344.3 & & & \\
\hline & $\begin{array}{l}\text { Umluj } \\
\text { station }\end{array}$ & 4103.1 & 5884.3 & 1148.1 & 3975.9 & 5246.7 & 1289.7 & 4188.2 & 6138.3 & 1095.7 & 4151.3 & 5573.5 & 1328.2 & & & \\
\hline \multirow[t]{2}{*}{ DEC } & $\begin{array}{c}\text { Al-Wajh } \\
\text { station }\end{array}$ & 3724.1 & 4945.3 & 1293.5 & 4039 & 5750 & 1206.4 & 4247.5 & 6647.4 & 1012.5 & 4030.5 & 5575.7 & 1300.1 & & & \\
\hline & $\begin{array}{l}\text { Duba } \\
\text { station }\end{array}$ & 3611 & 5047.5 & 1204.7 & 4014.6 & 6092.8 & 1074 & 4067.8 & 6651.7 & 944 & 3889.6 & 5686.4 & 1170 & & & \\
\hline
\end{tabular}






Figure 13. Field Solar Stations Map.

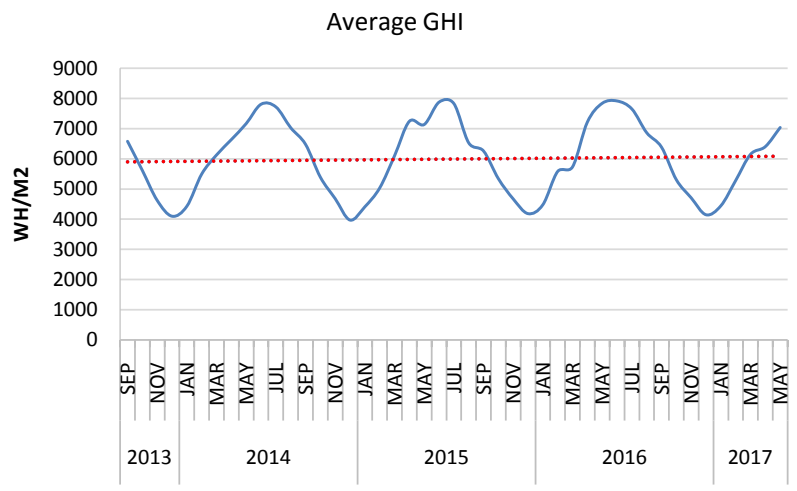

Figure 14. Average GHI Umluj (station \#1).

As shown in Figure 15, DNI mobile average corresponds to the below slope equation:

$$
y=-7.8179 x+6444.6
$$

this equation shows that is a slight decrement along the time period of the data.

As shown in Figure 16, DHI average corresponds to the below trend equation

$$
y=6.1121 x+1732.8
$$

this equation shows that is a steady increment along the time period of the data.

As shown in Figure 17, GHI average corresponds to the trend equation

$$
y=4.7295 x+5919.3
$$




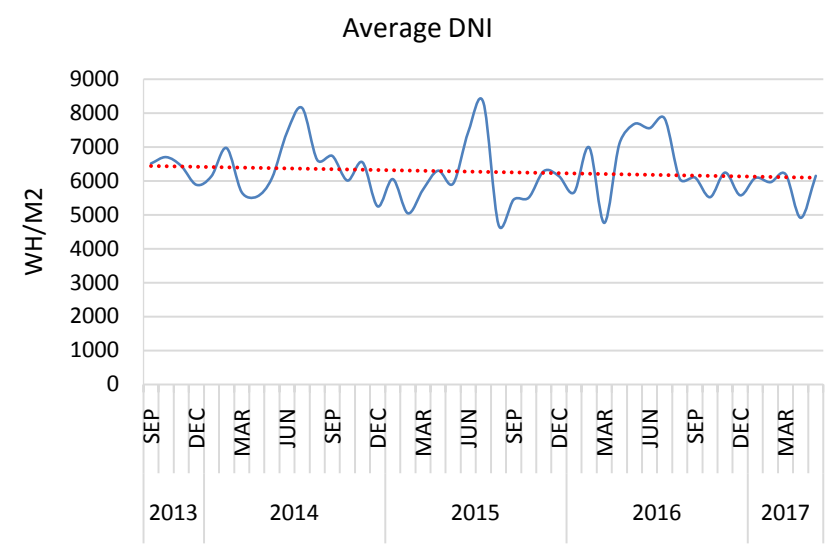

Figure 15. Average DNI Umluj (station \#1).

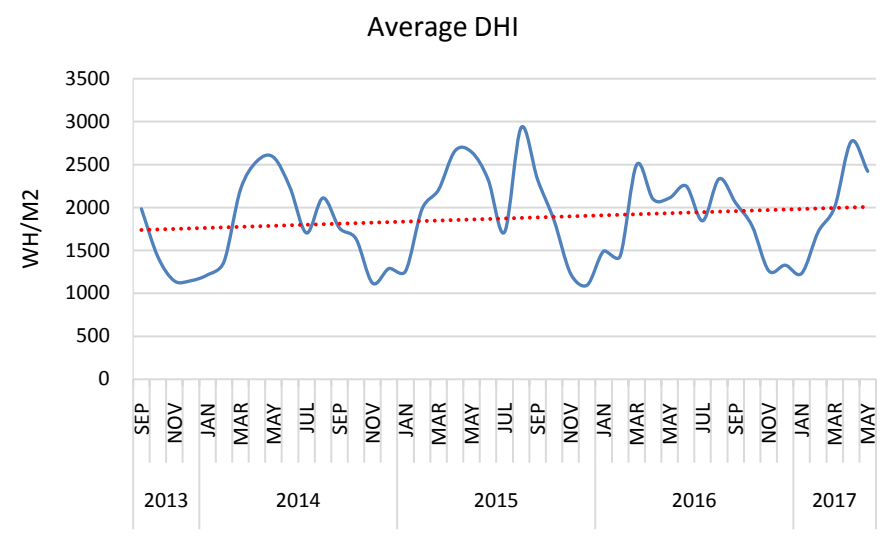

Figure 16. Average DHI Umluj (station \#1).

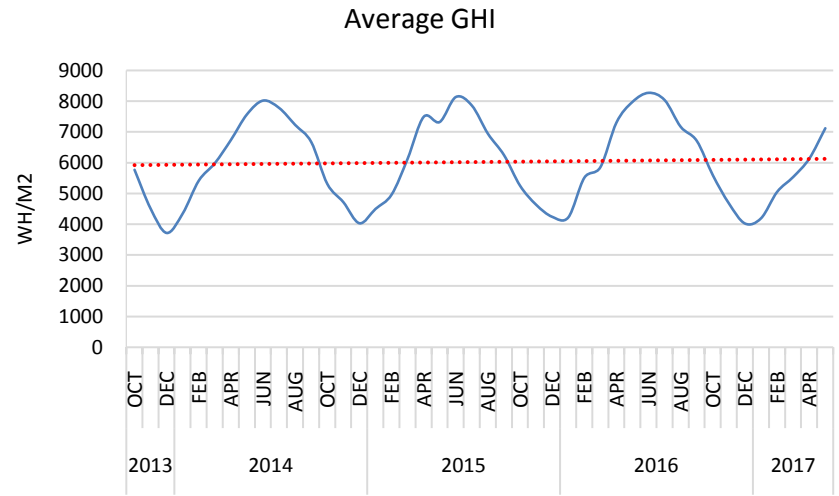

Figure 17. Average GHI Al-Wajh (station \#2).

that is a very slight increment along the time period of the data. It also closely corresponds to the same GHI average from station 1.

As shown in Figure 18, DNI average corresponds to the trend equation

$$
y=-8.5064 x+6857.3
$$

that is a slight decrement along the time period of the data. It also closely corresponds to the same DNI average from station 1. 
Interpretation: as shown in Figure 19, DHI average corresponds to the trend equation

$$
y=5.2022 x+1605.7
$$

that is a steady increment along the time period of the data. It also closely corresponds to the same DHI average from station \#1.

As shown in Figure 20, GHI average corresponds to the trend equation

$$
y=-0.7648 x+6057.7
$$

that remains steady along the time period of the data.

As shown in Figure 21, DNI average corresponds to the trend equation

$$
y=-11.889 x+7230.2
$$

that is a steady decrement along the time period of the data.

As shown in Figure 22, DHI average corresponds to the trend equation

$$
y=4.8305 x+1478.7
$$

that is a slight increment along the time period of the data.

According to the measurements gathered from the three ground stations et and according to graphs (from Figure 14 to Figure 22), the highest monthly average of GHI and DNI are observed in July with almost $8 \mathrm{KwH} / \mathrm{m}^{2}$.

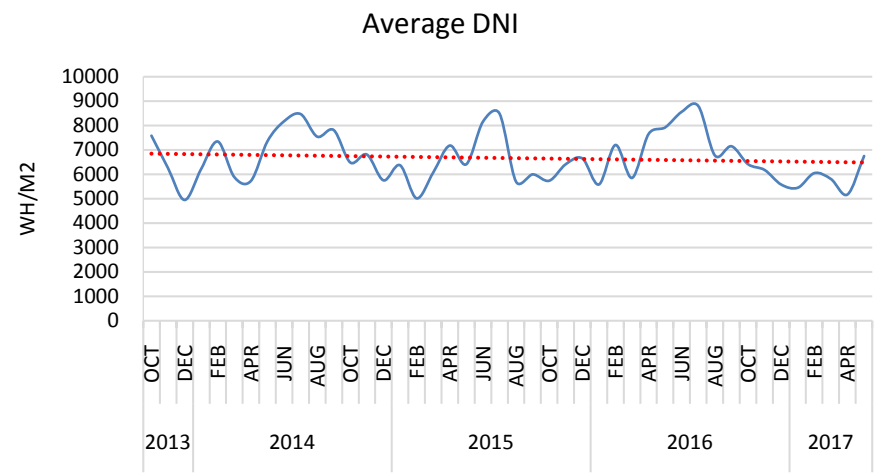

Figure 18. Average DNI Al-Wajh (station \#2).

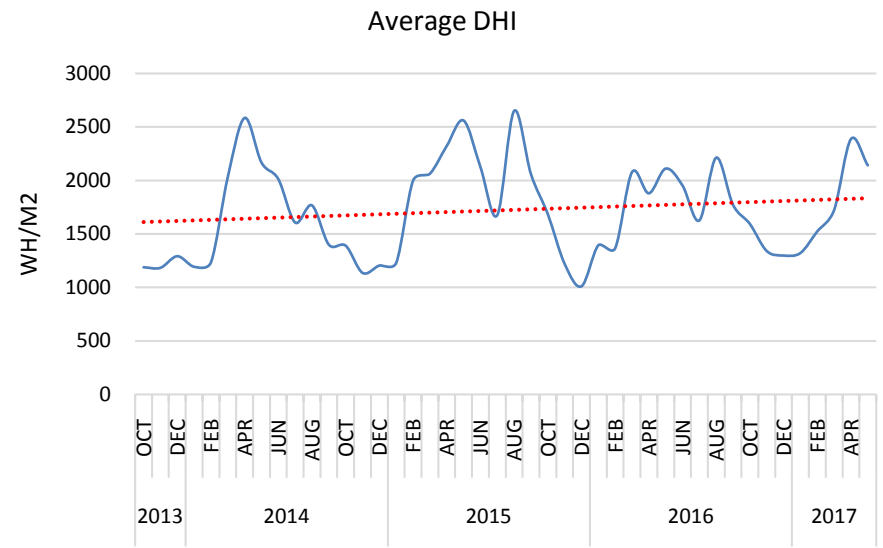

Figure 19. Average DHI Al-Wajh (station \#2). 




Figure 20. Average GHI Duba (Station \#3).

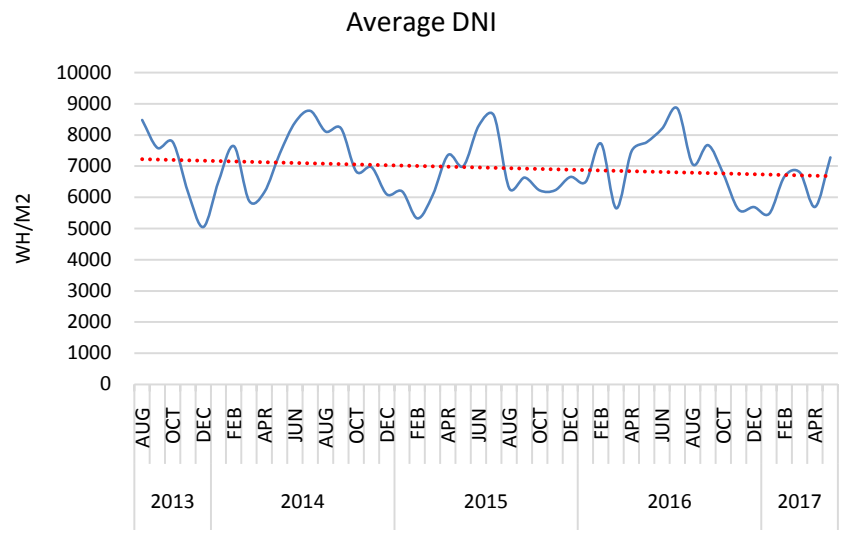

Figure 21. Average DNI Duba (station \#3).

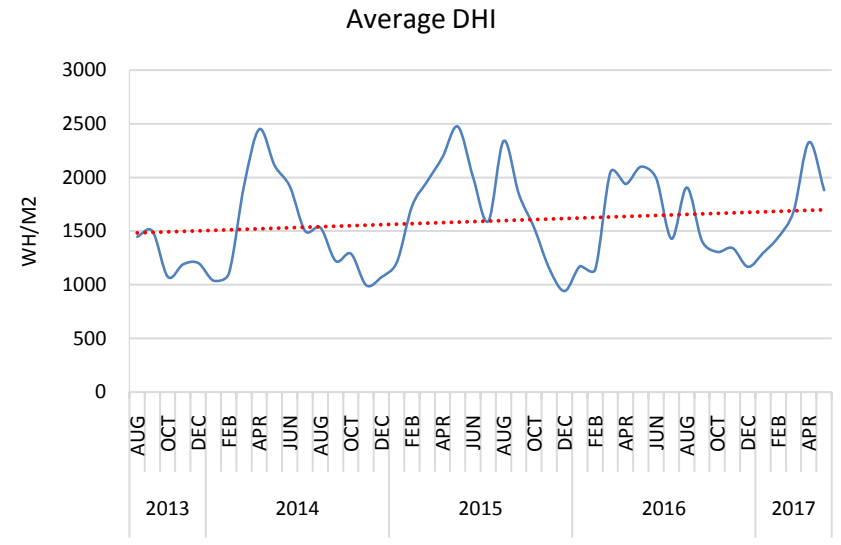

Figure 22. Average DHI Duba (station \#3).

With regard to the trends of the different measures, it can be said that it is difficult to pronounce on the trend of the evolution of the different measured parameters since the period of measurements is rather short.

For this reason, we used NASA-provided satellite data covering a period of about 17 years. These data relate to GHI measures. We have indeed used these 
data to compare them with the data collected by ground measurement stations and to reveal the trend of GHI.

The figure below (Figure 23), shows GHI measured by Al-Wajh ground station and measures derived from satellites. The measurements are in good agreement, however we calculated the rBias between the two sets of measurements, and we can observe that the rBias between data has an average of $3 \%$ with a maximum of $18 \%$ (see Figure 24 ).

Rhe trend of GHI measurements has been made on satellite-collected measurements because they cover a period of about 17 years. Contrary to the figures on which there is a slight increase in the GHI values for the two stations of Umluj and Al-Wajh (Figure 14 and Figure 17), the general trend is rather downward as shown in Figure (Figure 25).

\subsection{Table Summaries}

Tables 2-4 summarize the data limits and averages from data sources by measurement stations.

The yield in the study area for DNI \& GHI considerably, as designated in $\mathrm{Ta}$ ble 5 , ranges from 6000 to $7000 \mathrm{Wh} / \mathrm{m}^{2}$. It indicates to be significant amount. This affirms to the results from the previous study mentioned in this research [17].

Table 5 shows the total average of all indices of total records. Reference to Equation (1), Azimuth angle can be calculated as shown in the table.

Table 2. Umluj station data limits.

\begin{tabular}{cccc}
\hline & DHI & DNI & GHI \\
\hline Min & 1095.7 & 4704.7 & 3975.9 \\
Max & 2928 & 8311.9 & 7912.4 \\
Avg & 1873.4178 & 6264.7467 & 5991.813 \\
\hline
\end{tabular}

Table 3. Al-Wajh station data limits.

\begin{tabular}{cccc}
\hline & DHI & DNI & GHI \\
\hline Min & 1012.5 & 4945.3 & 3724.1 \\
Max & 2652.6 & 8794.2 & 8274.4 \\
Avg & 1722.734 & 6665.9295 & 6025.712 \\
\hline
\end{tabular}

Table 4. Duba station data limits.

\begin{tabular}{cccc}
\hline & DHI & DNI & GHI \\
\hline Min & 944 & 5047.5 & 3611 \\
Max & 2476.8 & 8847.1 & 8090.9 \\
Avg & 1592.25 & 6950.8348 & 6039.722 \\
\hline
\end{tabular}


Table 5. Total final average of all data sources.

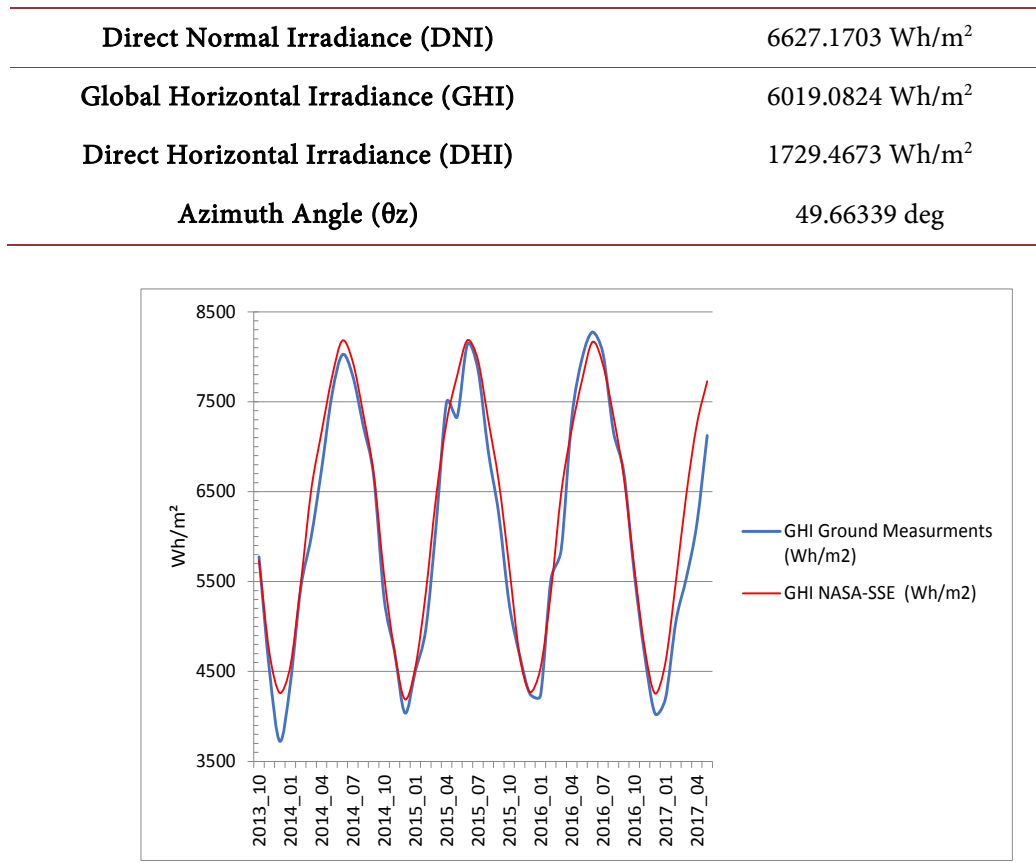

Figure 23. comparaison between ground measurments and Satellite measurments.

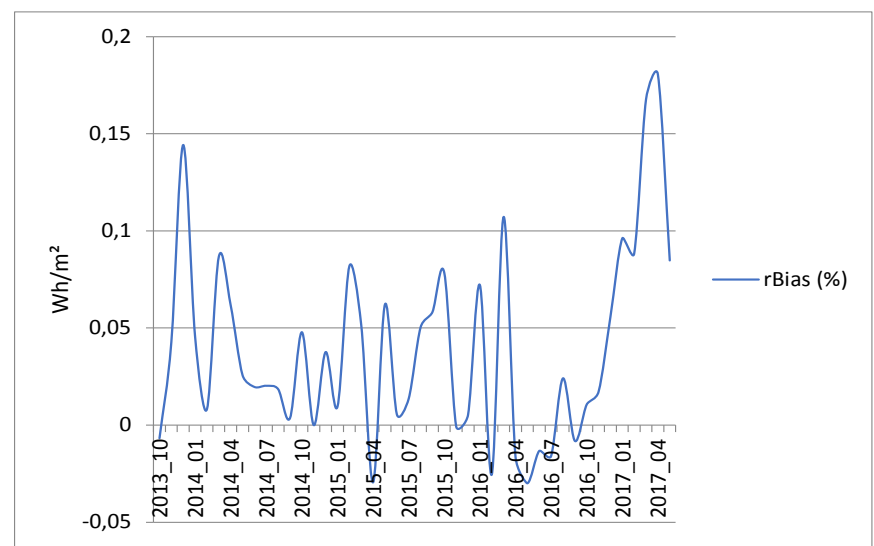

Figure 24. rBias between ground measurments and Satellite measurments.

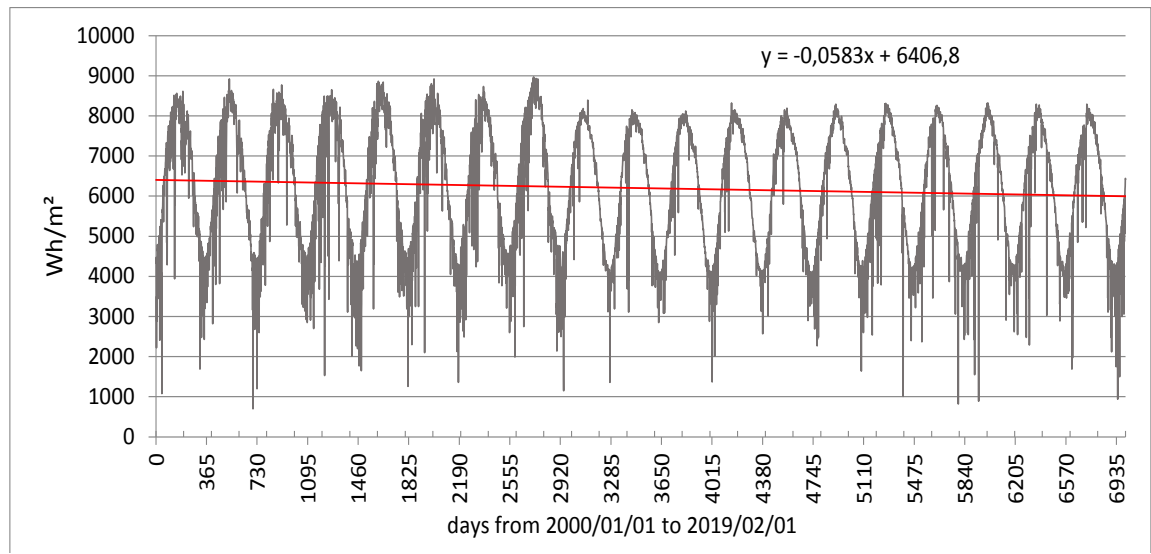

Figure 25. GHI trend-Satellite derived data. 


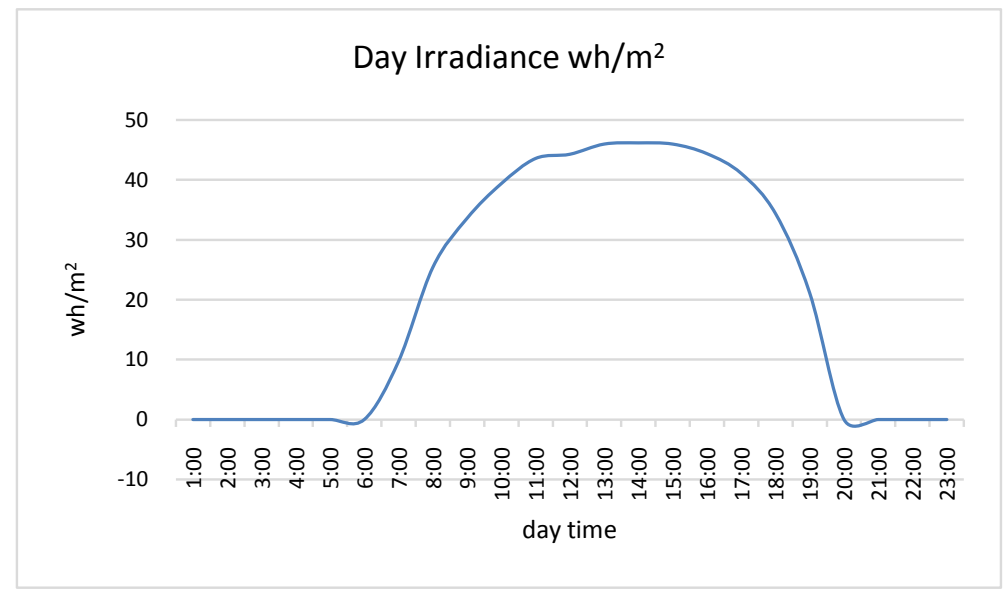

Figure 26. Day irradiance.

\section{Results and Discussions}

The goal was to investigate the rate of direct solar radiation, direct global radiation, and diffused radiation, by analyzing these elements and exploring the correlations between them, demonstrating the intensity of solar radiation as per the sampling locations. As per Table 5, GHI was found to be around 6019.082 $\mathrm{Wh} / \mathrm{m}^{2}$ and DHI found to be around $6627.1703 \mathrm{Wh} / \mathrm{m}^{2}$.

The figures as shown by the resulted tables were slanted to high rates; the outcomes tended to rise with a high normal or the like. This is an underlying sign of the speculation of a high ratio of sun radiation in the study area. The investigation performed on the information is quantitative with a specific end goal to help envision the average rate of radiation and the measure of vitality that can be created at this site.

The zone of the Red Sea project is rich with sun radiation consistently and the climate is steady and clear more often than not, notwithstanding the number of hours of daylight is very high as shown in Figure 26.

Also, current costs of the technology and constraints on financial support indicate that only projects that are located in the areas with the highest DNI are likely to be viable in the near future with annual average DNI values greater than $2.2 \mathrm{MWh} / \mathrm{m}^{2} /$ year or $6 \mathrm{KWh} / \mathrm{m}^{2} /$ day.

Every one of these assumptions might be considered as profitable factor relating the speculation of solar radiation in the study area.

\section{Acknowledgements}

Special thanks to King Abdullah city for renewable energy for their cooperation providing the data used in this research.

\section{Conflicts of Interest}

The authors declare no conflicts of interest regarding the publication of this paper. 


\section{References}

[1] Jakubiec, A. and Reinhart, C. (2012) Towards Validated Urban Photovoltaic Potential and Solar Radiation Maps Based on Lidar Measurements, Gis Data, and Hourly Daysim Simulations. Proceedings of Simbuild, Madison, 1-10.

[2] Resch, B., Sagl, G., Törnros, T., Bachmaier, A., Eggers, J.-B., Herkel, S., et al. (2014) GIS-Based Planning and Modeling for Renewable Energy: Challenges and Future Research Avenues. ISPRS International Journal of Geo-Information, 3, 662-692. https://doi.org/10.3390/ijgi3020662

[3] Hoesen, J.V. and Letendre, S. (2010) Evaluating Potential Renewable Energy Resources in Poultney, Vermont: A GIS-Based Approach to Supporting Rural Community Energy Planning. Renewable Energy, 35, 2114-2122. https://doi.org/10.1016/j.renene.2010.01.018

[4] World Bank Group (2017) Solar Resource and Photovoltaic Potential of Myanmar. World Bank Group (ESMAP), Solar Resource and Photovoltaic Power Potential of Myanmar, Project ID: P150328.

[5] Dawod, G., Al-Ghamdi, K. and Mandoer, M. (2017) Optimum Sites for Solar Energy Harvesting in Makkah Metropolitan Area Based on Multi-Criteria GIS. The 11th National Conference on GIS Applications, Imam Abdul Rahman Bin Faisal Univer-sity, Dammam, Saudi Arabia, 11-13 April 2017. (In Arabic)

[6] Usta, Z., Comert, C. and Yilmaz, V. (2017) Solar Energy Potential of Cities in Turkey; A Gis Based Analysis. Fresenius Environmental Bulletin, 26, 80-83.

[7] Wang, Q., Mwirigi M'Ikiugu, M. and Kinoshita, I. (2014) A GIS-Based Approach in Support of Spatial Planning for Renewable Energy: A Case Study of Fukushima, Japan. Sustainability, 6, 2087-2117. https://doi.org/10.3390/su6042087

[8] Gately, D., Al-Yousef, N. and Al-Sheikh, H.M.H. (2012) The Rapid Growth of Domestic Oil Consumption in Saudi Arabia and the Opportunity Cost of Oil Exports Foregone. Energy Policy, 47, 57-68. https://doi.org/10.1016/j.enpol.2012.04.011

[9] Bithas, K. and Kalimeris, P. (2016) Revisiting the Energy-Development Link. Springer Briefs in Economics.

[10] Smil, V. (2006) Energy at the Crossroads. Global Science Forum Conference on Scientific Challenges for Energy Research.

[11] Elliott, D. (2000) Renewable Energy and Sustainable Futures. Futures, 32, 261-274. https://doi.org/10.1016/S0016-3287(99)00096-8

[12] Alrkiyan, S., Alradhi, A. and Alharbi, E. (2017) Designofhybrid PV-TEC System. Bank, S. W. Global Solar Atlas.

[13] Effat, H. (2014) Spatial Modeling of Optimum Zones for Wind Farms Using Remote Sensing and Geographic Information System, Application in the Red Sea, Egypt. Scientific Research Publishing Inc.

[14] Dawod, G. and Mandoer, M. (2016) Optimum Sites for Solar Energy Harvesting in Egypt Based on Multi-Criteria GIS. The First Future University International Conference on New Energy and Environmental Engineering, At Cairo.

[15] Marcovecchio, J. (2000) Land-Based Sources and Activities Affecting the Marine Environment at the Upper Southwestern Atlantic Ocean: An Overview. UNEP Regional Seas Reports \& Studies, 170, 67.

[16] Effat, H. (2016) Mapping Solar Energy Potential Zones, Using SRTM and Spatial Analysis, Application in Lake Nasser Region, Egypt. International Journal of Sustainable Land Use and Urban Planning, 3, 1-14.

[17] Zell, E., et al. (2015) Assessment of Solar Radiation Resources in Saudi Arabia. Solar Energy, 119, 442-438. https://doi.org/10.1016/j.solener.2015.06.031 